\title{
A noteworthy accumulation of disparid crinoids from the type Cincinnatian (Upper Ordovician) of southwestern Ohio, USA: implications for the palaeoecology and taphonomy of crinoid "logjam" assemblages
}

\author{
James R. Thomka ${ }^{1}$ Carlton E. Brett ${ }^{2} \cdot$ Troy A. Bole $^{3} \cdot$ Hunter J. Campbell ${ }^{1}$
}

Received: 3 June 2018/Accepted: 3 August 2018/Published online: 21 August 2018

(C) Akademie der Naturwissenschaften Schweiz (SCNAT) 2018

\begin{abstract}
Crinoids are a common and well-studied faunal component of the Upper Ordovician (Katian; Edenian) Kope Formation in the greater Cincinnati Arch region, USA. However, a relatively fresh outcrop exposing the Southgate and McMicken members of the Kope Formation at Cleves, Hamilton County, southwestern Ohio, has yielded a crinoid specimen worthy of description and comment. The specimen is a "logjam" of numerous articulated columns of Iocrinus subcrassus displaying parallel alignment, reflecting the influence of storm-generated currents. Iocrinus is not typically found in such a state; the genera Ectenocrinus and Cincinnaticrinus are generally associated with "logjams" in the type Cincinnatian, making this an unusual occurrence. At least one of the columns has the coiled dististele of another, smaller I. subcrassus tightly wrapped around it. Although I. subcrassus is known to employ a coiled dististele as an attachment strategy, ramose bryozoans are generally utilised as substrates and tight coiling around larger I. subcrassus columns has not previously been reported. Preservation of coiled dististeles, in general, is a feature not previously documented in Cincinnatian crinoid "logjams." This specimen illustrates that unusual, noteworthy and/or rare material representing relatively common organisms continue to be discovered even within extensively studied units in the type Cincinnatian.
\end{abstract}

Keywords Echinodermata $\cdot$ Iocrinus subcrassus $\cdot$ Kope Formation · Katian · Attachment structures

\section{Introduction}

The type Cincinnatian (Upper Ordovician, Katian) succession of the greater Cincinnati Arch region, eastern midcontinental USA, is recognised as one of the most exhaustively studied stratigraphic intervals in North America (see syntheses in Davis and Cuffey 1998; McLaughlin et al. 2008; Meyer and Davis 2009). Crinoids

Editorial Handling: Daniel Marty.

James R. Thomka

jthomka@uakron.edu

1 Department of Geosciences, University of Akron, Akron, OH 44325, USA

2 Department of Geology, University of Cincinnati, Cincinnati, OH 45221, USA

3 Department of Geosciences, Florida Atlantic University, Boca Raton, FL 33431, USA are a fossil group that is fairly ubiquitous throughout the type Cincinnatian, serving as the primary subject of numerous systematic, palaeoecological and taphonomic studies (e.g., Ausich 1996, 1999; Donovan and Schmidt 2001; Meyer et al. 2002; Brett et al. 2008; Kallmeyer and Ausich 2015). Nevertheless, important and interesting discoveries related to the distribution and preservation of crinoids continue to be made as novel analytical techniques are applied to datasets and new exposures are described and sampled.

The present note represents a description of a crinoid specimen from a relatively fresh outcrop of the Cincinnatian Kope Formation in Ohio, USA. This occurrence presents an opportunity to document in detail hitherto undescribed palaeontological and sedimentological aspects of crinoid fossils within an interval known for an abundance of crinoidal material. As recently emphasised by Kallmeyer and Ausich (2015), such occurrences have the potential to revise broader palaeocommunity models and 
palaeoecological interpretations, making documentation of interesting and/or rare specimens a significant contribution.

\section{Locality and stratigraphy}

Described material was collected from an outcrop along the entrance to the River's Edge Indoor Sports Complex at Cleves, Hamilton County, southwestern Ohio (N39 $11^{\prime} 42^{\prime \prime}$, W84 $37^{\prime} 15^{\prime \prime}$; Fig. 1), a short distance northwest of the Cincinnati metropolitan area. This locality has been previously described in detail by Brett et al. (2012, p. 54-57) and is significant because of its freshness relative to nearby roadcuts. The middle and upper portions of the lower Cincinnatian (Edenian) Kope Formation, specifically the upper Southgate Member and lower McMicken Member, are well exposed. Specimens were collected as float from the upper part of the cut along the main driveway leading up to the parking lot, indicating provenance from the Grand View submember of the Southgate Member or Grand Avenue submember of the McMicken Member (Brett et al. 2012).

\section{Description of material}

The basis for this study consists of an irregular, pod-like bed of normally graded siltstone, approximately $100 \mathrm{~mm}$ in length, $60 \mathrm{~mm}$ in width and $35 \mathrm{~mm}$ in thickness (Fig. 2), and reposited in the Cincinnati Museum Center (Cincinnati, Ohio, USA) as CMC IP79901. The lower surface consists of a coarse hash of skeletal debris, including abundant isolated crinoid columnals belonging to at least two genera (Iocrinus and Ectenocrinus; Fig. 2b), which forms the base of the graded bed. The upper surface consists of quartz silt representing the fine-grained cap to the bed (Fig. 2a). Disseminated throughout the upper $80 \%$ of the slab are articulated lengths of crinoid columns attributable to the disparid Iocrinus subcrassus (Fig. 2). The articulated material comprises a monospecific assemblage, with such diagnostic features as a pentastellate (to pentagonal) columnal outline with a centrally located, circular lumen, coupled with a distinctive and consistent heteromorphic noditaxial pattern (Meyer et al. 2002). No isolated columnals are present except for the bioclastic material at the base of the bed (Fig. 2b), and no complete or partial crowns are within the bed or exposed on surfaces (Fig. 2).

Columns are noticeably aligned, being oriented parallel to slightly oblique to the long axis of the slab (Fig. 2). However, nearly all columns are somewhat curved, resulting in alignment that is not as prominently unidirectional as that observed in certain other crinoid columndominated assemblages, namely the so-called "logjam" assemblages (see below). The curvature of columns may reflect the flexibility of the column to some extent (Baumiller and Ausich 1996), but the consistency in orientation indicates that a more likely factor is shifting current directions throughout the duration of the event associated with burial.

The coiled dististele of a juvenile I. subcrassus is wrapped tightly around one of the articulated columns (Fig. 2c) on the lower surface of the slab. Two complete whorls are visible. Columnals of the coiled dististele are cuneiform in lateral view, indicating permanent attachment from an initial (larval) settling point on the erect column
Fig. 1 Locality map showing the site (marked by the asterisk) in Cleves, Hamilton County, southwestern Ohio, from where the studied material was collected. See Brett et al. (2012) for a detailed description of the stratigraphy of this site

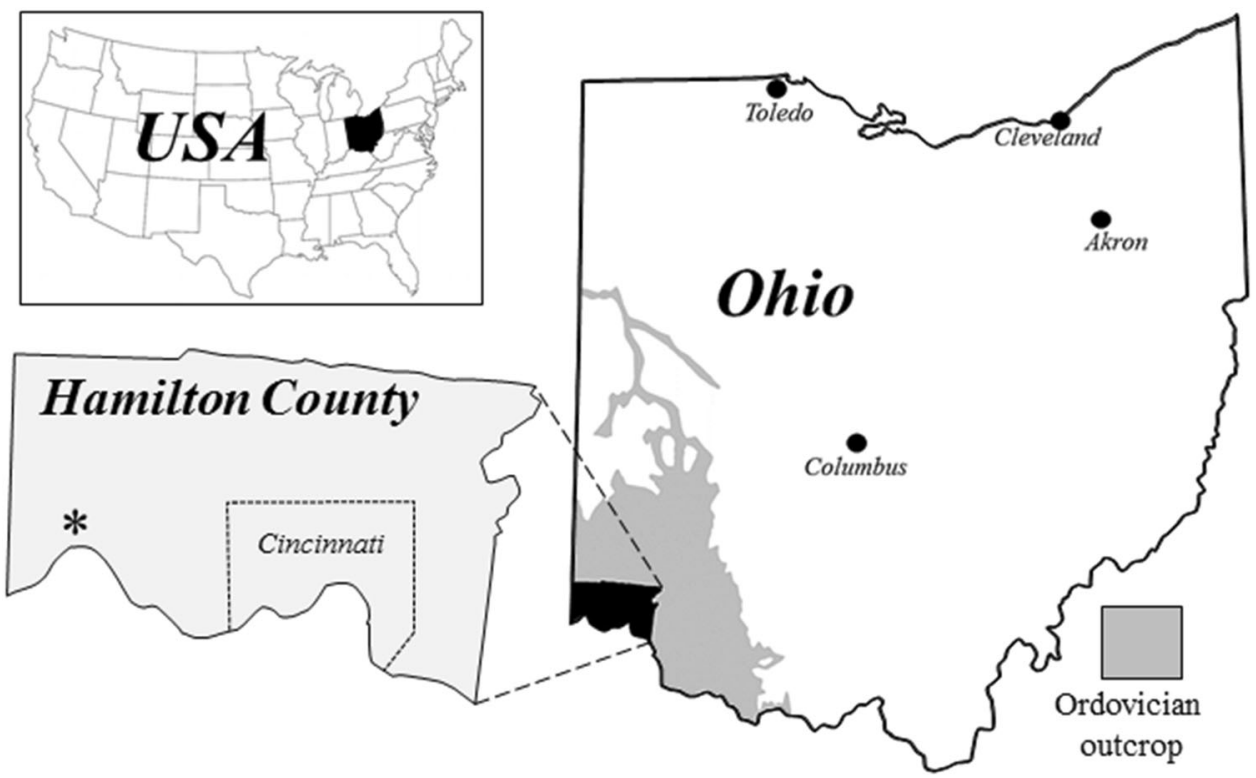



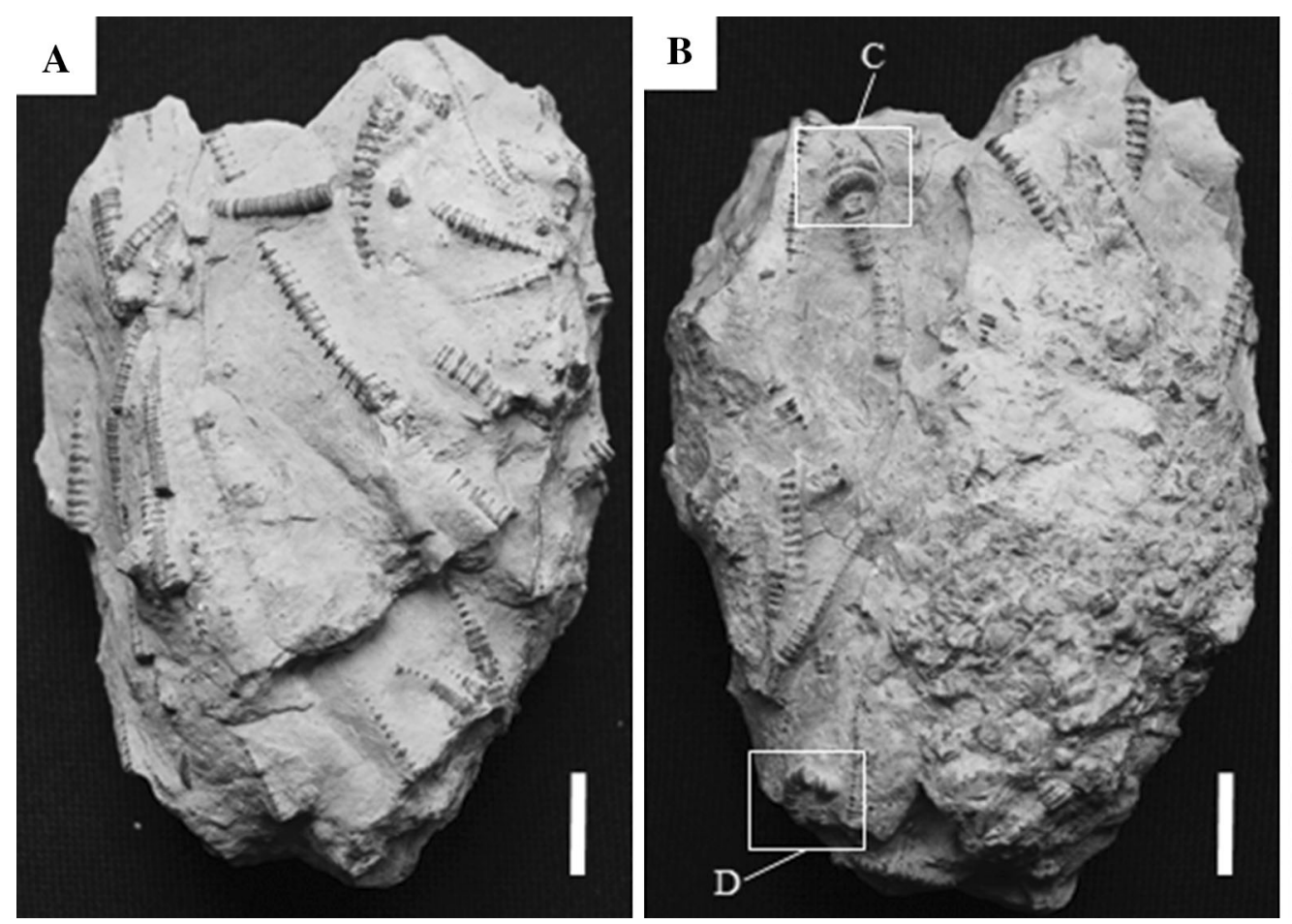

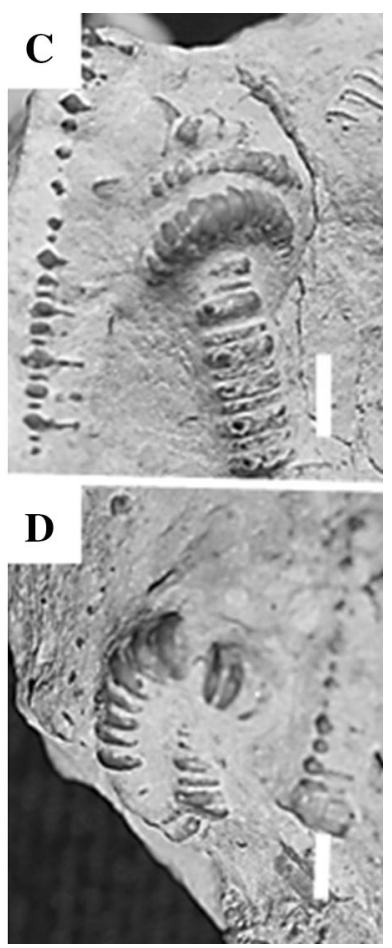

Fig. 2 An Iocrinus subcrassus "logjam" from the Kope Formation (CMC IP79901). a View of upper surface of graded siltstone bed showing aligned, slightly curved $I$. subcrassus stems. Scale bar $=10$ $\mathrm{mm}$. b View of lower surface of bed, showing basal skeletal hash, representing the base of the graded bed, overlain by aligned I. subcrassus stems. The areas enlarged in panels C and D of this figure are indicated. Note that the image has been rotated to maintain the same outline shown in panel A. Scale bar $=10 \mathrm{~mm}$. c Coiled

(Brett et al. 2008). Another portion of a column appears to be wrapped around a stem at the opposite end of the same surface of the slab (Fig. 2d), but it is more loosely coiled and therefore may not represent an attached dististele.

\section{Implications for locrinus palaeoecology}

Iocrinus subcrassus is known to utilise a coiled dististele to attach to substrates; however, ramose bryozoan zoaria are generally used as substrata (Ausich 1999; Brett et al. 2008). In some instances, I. subcrassus dististeles are found in coils that are not wrapped around a particular bioclast or lithoclast (e.g., Brett et al. 2008, Fig. 2.7), but the diameters of these coils are invariably too large to represent another crinoid column as a primary substrate. It seems unlikely that this represents relaxation of coiling as a result of post-mortem decay because of the articulated state of such specimens. Perhaps unmineralized substances such as algae were encrusted, as suggested for Glyptocrinus (see Milam et al. 2017), or certain individuals simply developed a looser coil during ontogeny. Regardless, I. subcrassus columns have not been documented previously as substrata
I. subcrassus dististele wrapped tightly around one of the stems visible in panel B. Note that coiled dististeles have not previously been described from crinoid "logjam" assemblages, and that $I$. subcrassus is not known to wrap around other stems. Scale bar $=5 \mathrm{~mm}$. d Possible coiled I. subcrassus dististele wrapped around one of the stems visible in panel B. This is somewhat loosely coiled, so it may represent a coincidental relationship rather than true attachment. Scale bar $=5 \mathrm{~mm}$

for encrustation by juveniles. The tightness of coiling and cementation indicates that this was not a temporary association, but a permanent life strategy.

Monospecific crinoid column assemblages serve as evidence of gregarious life habits. It has been hypothesised, based on analysis of other crinoid assemblages, that a gregarious ecology may be related to larval settling strategies (e.g., Jagt et al. 2010; Thomka and Brett 2017). The articulated state of columns in this specimen indicate that the crinoids were likely buried alive or very shortly after death (Brett et al. 1997; Ausich 2001), demonstrating an association that had been established before burial. Hence, it can be concluded that I. subcrassus utilised the stems of older conspecific generations as permanent attachments, and this likely contributed to the development of dense, monospecific communities.

\section{Taphonomy of crinoid "logjam" deposits}

Crinoid "logjams" are accumulations of densely packed, aligned, articulated columns, typically all belonging to a single species. The articulated state of columns and their 
directional alignment indicate a high-energy event associated with relatively strong currents and rapid burial (Brett and Baird 1986; Ausich 2001); it also indicates the presence of dense, often monospecific stands of crinoids on the seafloor that were disrupted but remained locally aggregated (Brett et al. 2008). Although crinoid "logjams" are known from many deposits throughout the Palaeozoic and Mesozoic, the type Cincinnatian possibly contains the most common, stratigraphically consistent and/or well-studied of such accumulations, likely because of the abundance of storm deposits (e.g., Brett et al. 2003; Meyer and Davis 2009).

The specimen described herein qualifies as a "logjam" based on the abundance of articulated columns and their alignment. "Logjam" assemblages containing abundant Iocrinus columns are relatively rare; in the type Cincinnatian, "logjams" far more commonly consist of material attributable to the disparid genera Ectenocrinus and Cincinnaticrinus (Brett et al. 2008). Other Cincinnatian accumulations of articulated Iocrinus columns display fairly random orientations (e.g., Meyer and Davis 2009, p. 178). Yet, despite being a "logjam", this accumulation is characterised by a long-axis alignment that is not as strong as other "logjams" from the type Cincinnatian (e.g., Brett et al. 2003, Fig. 6C, 2008, Figs. 2.5, 2.9; Meyer and Davis 2009, pl. 10B) and in other settings (e.g., Donovan 2012b, Figs. 1, 2; Simms 1989, pl. 2.1).

This pattern may be due to the formation of many typical crinoid "logjams" within erosionally generated structures such as scours or gutter casts, which would result in stronger unidirectional alignment, keeping stems parallel even if current changes direction. Indeed, in certain examples, a strong shift has been observed in predominant direction by nearly $90^{\circ}$ from base to top of the same accumulation, indicating a rotation of current during a single event (Brett et al. 2012). Alternatively, strength of alignment may be related to the difference between columns that were rooted to the substrate versus detached columns. Anchored columns would likely become strongly aligned parallel to current (Brett and Eckert 1982; Brett et al. 1997) whereas completely allochthonous columns may be reoriented by shifts in current direction. Previous taphonomic studies of Iocrinus assemblages in the type Cincinnatian have described examples of articulated crowns that were separated from columns and transported downslope before being covered by the associated uprooted columns (Meyer et al. 1981). This may suggest that $I$. subcrassus was more prone to being physically disarticulated (removal of crowns), uprooted and eventually transported relative to other crinoid taxa that remained attached to the substrate. Whereas Iocrinus was attached by a relatively small distal coil, the otherwise similar disparid taxa Ectenocrinus and Cincinnaticrinus are known to use a
Lichenocrinus-type discoidal holdfast to cement to hard substrata (Brett et al. 2008), perhaps allowing these taxa to remain anchored for a longer duration during storm events (although the rarity of columns articulated to Lichenocrinus specimens may indicate that detachment was common for those taxa as well). Another potential explanation is that this taxon may have been more prone to voluntarily detach, or autotomize, portions of the skeleton under stress (see Donovan 2012a), leading to an increased abundance of columns detached from attachment structures (and probably crowns detached from columns).

Interpreting palaeocurrent direction from crinoid "logjams" is difficult based on material that is collected as float. Brett et al. (2003) interpreted crinoid "logjams" in the type Cincinnatian as being oriented roughly perpendicular to current direction, possibly accumulating between the crests of ripple marks formed during storm events. This is supported by some experimental and field studies (Schwarzacher 1963; Nagle 1967) that described the tendency of loose pluricolumnals to roll when exposed to unidirectional currents. It is also supported by tool marks in the Kope Formation, including specimens from the same locality as the "logjam" (Fig. 3), that show distinctive parallel grooves made by nodal columnals as pluricolumnals rolled perpendicular to their long axes (Brett and Algeo 2001). However, significant scatter can be observed in column orientations in a single sample and other studies have indicates that certain "logjams" are oriented parallel to predominant current direction (e.g., Donovan 2012b). Experimental work by Schwarzacher (1963) suggested that primary current sense is indicated by the bisector of the obtuse angle formed by the two most common column/pluricolumnal orientations, which may correspond to the slight apparent difference in column orientations between the upper and lower surfaces of the specimen. Unfortunately, it seems that this specimen is not presently capable of providing reliable data on current direction in spite of clearly being strongly influenced by currents or other water movement.

There is no significant difference in preservation of $I$. subcrassus columns between the top and bottom of the bed (Fig. 2). This contrasts with some event deposits in which the upper surface has been disrupted, reflecting a return to low sedimentation conditions following a rapid burial event (Brett and Baird 1986). Examination of the crosssectional views of the slab reveals no evidence for crowns in the interior or toward the bottom of the accumulation of columns, as noted in some other occurrences in which these fragile components were apparently protected by the overlying mass of rapidly deposited material (Meyer et al. 1981; Brett et al. 1997). Either the crowns were completely autotomized prior to burial, the "cut effect" (sensu Donovan 2012b) prevented recognition of crowns because 


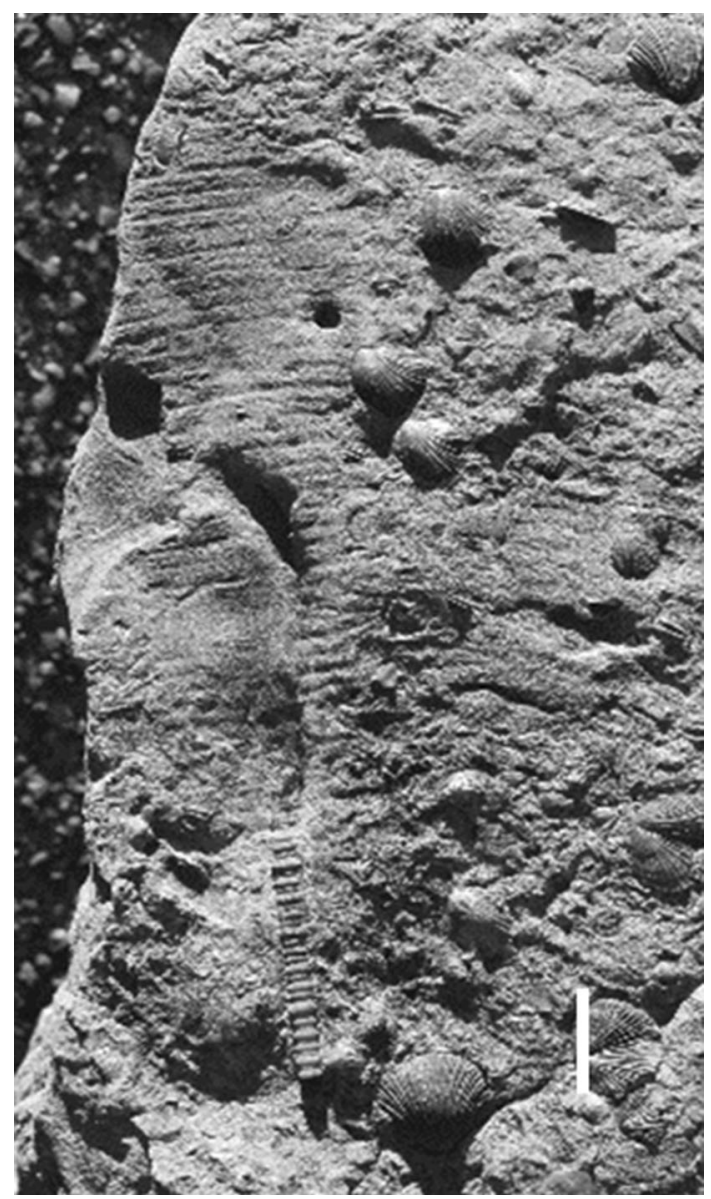

Fig. 3 Example of parallel, slightly arcuate tool marks produced by the dragging of Ectenocrinus simplex nodals perpendicular to the long axis of the pluricolumnal. This specimen, which was recovered from the same locality as the "logjam" in Fig. 2, illustrates that elongate crinoid remains can be oriented with a long axis perpendicular to current direction, as has been suggested for certain "logjams" in the type Cincinnatian. Scale bar $=10 \mathrm{~mm}$

of the small size of the slab and the limited surface area of cross-sectional view, or the columns were sufficiently long to minimise the likelihood of crowns being visible on a single slab. Serial slicing perpendicular to the long axis of the slab might reveal crowns that are concealed beneath higher columns, but this would result in the severe damaging of a rare and noteworthy specimen.

\section{Conclusions}

A crinoid "logjam" consisting of articulated columns belonging to the disparid Iocrinus subcrassus is described from the Upper Ordovician (Katian) Kope Formation of southwestern Ohio, USA. Alignment is not as strong as that displayed in other "logjams" but nevertheless indicates the effects of strong currents, likely associated with storm events. I. subcrassus "logjams" are relatively rare in the type Cincinnatian. At least one column in the present occurrence has the coiled dististele of a juvenile individual wrapped tightly around it, a feature not previously documented in crinoid "logjam" assemblages. This species generally coils around ramose bryozoan zoaria; the ability to utilise erect columns of older individuals likely contributed to the development of dense monospecific aggregations. This specimen is more similar to typical "logjams" consisting of the columns of crinoid taxa such as Ectenocrinus and Cincinnaticrinus than to other aggregations of articulated Iocrinus material. In general, this occurrence indicates that rare and/or palaeoecologically significant discoveries continue to be made even within extensively studied stratigraphic intervals and pertaining to relatively common and ubiquitously distributed organisms.

Acknowledgements The owners and management of the River's Edge Indoor Sports Complex at Cleves, Ohio are thanked for allowing access to this locality. Earlier versions of this paper were significantly improved by the constructive reviews by William I. Ausich (Ohio State University) and David L. Meyer (University of Cincinnati). This is a contribution to the International Geoscience Programme Project 653: "The Onset of the Great Ordovician Biodiversification Event".

\section{References}

Ausich, W. I. (1996). Phylum Echinodermata. In R. M. Feldmann (Ed.), Fossils of Ohio (pp. 242-261). Ohio Geological Survey Bulletin 70.

Ausich, W. I. (1999). Upper Ordovician of the Cincinnati, Ohio, area, USA. In H. Hess, W. I. Ausich, C. E. Brett, \& M. J. Simms (Eds.), Fossil Crinoids (pp. 75-80). Cambridge: Cambridge University Press.

Ausich, W. I. (2001). Echinoderm taphonomy. In M. Jangoux \& J. M. Lawrence (Eds.), Echinoderm Studies 6 (pp. 171-227). Rotterdam: A. A. Balkema.

Baumiller, T. K., \& Ausich, W. I. (1996). Crinoid stalk flexibility: Theoretical predictions and fossil stalk postures. Lethaia, 29, 47-59.

Brett, C. E., \& Algeo, T. J. (2001). Event beds and small-scale cycles in Edenian to lower Maysvillian strata (Upper Ordovician) of northern Kentucky: Identification, origin, and temporal constraints. In T. J. Algeo \& C. E. Brett (Eds.), Sequence, Cycle, and Event Stratigraphy of Upper Ordovician and Silurian Strata of the Cincinnati Arch Region (pp. 65-92). Kentucky Geological Survey Guidebook 1.

Brett, C. E., Algeo, T. J., \& McLaughlin, P. I. (2003). Use of event beds and sedimentary cycles in high-resolution stratigraphic correlation of lithologically repetitive successions: The Upper Ordovician Kope Formation of northern Kentucky and southern Ohio. In P. J. Harries (Ed.), Approaches in High-Resolution Stratigraphic Paleontology (pp. 315-350). Amsterdam: Kluwer Academic Press.

Brett, C. E., \& Baird, G. C. (1986). Comparative taphonomy: A key to paleoenvironmental interpretation based on fossil preservation. Palaios, 1, 207-227.

Brett, C. E., Deline, B. L., \& McLaughlin, P. I. (2008). Attachment, facies distribution, and life history strategies in crinoids from the Upper Ordovician of Kentucky. In W. I. Ausich \& G. D. Webster 
(Eds.), Echinoderm Paleobiology (pp. 22-52). Bloomington: Indiana University Press.

Brett, C. E., \& Eckert, J. D. (1982). Palaeoecology of a wellpreserved crinoid colony from the Silurian Rochester Shale in Ontario. Royal Ontario Museum Life Sciences Contributions, $131,1-20$.

Brett, C. E., Moffat, H. A., \& Taylor, W. L. (1997). Echinoderm taphonomy, taphofacies, and Lagerstätten. In J. A. Waters \& C. G. Maples (Eds.), Geobiology of Echinoderms (pp. 147-190). Paleontological Society Papers 3.

Brett, C. E., Schramm, T. J., Dattilo, B. F., \& Marshall, N. T. (2012). Upper Ordovician strata of southern Ohio-Indiana: Shales, shell beds, storms, sediment starvation, and cycles. Cincinnati: Geological Society of America, North-Central Section Field Trip Guidebook.

Davis, R. A., \& Cuffey, R. J. (Eds.). (1998). Sampling the layer cake that isn't: The stratigraphy and paleontology of the TypeCincinnatian. Columbus: Oho Division of Geological Survey Guidebook 13.

Donovan, S. K. (2012a). Was autotomy a pervasive adaptation of the crinoid stalk during the Paleozoic? Geology, 40, 867-870.

Donovan, S. K. (2012b). An unusual accumulation of crinoids from the Silurian of the Howgill Fells, Cumbria, UK. Proceedings of the Yorkshire Geological Society, 59, 121-123.

Donovan, S. K., \& Schmidt, D. A. (2001). Survival of crinoid stems following decapitation: Evidence from the Ordovician and palaeobiological implications. Lethaia, 34, 263-270.

Jagt, W. J. M., Donovan, S. K., \& Deckers, M. J. M. (2010). Clustered bourgueticrinid crinoid holdfasts on late Maastrichtian echinoids from northeast Belgium and southeast Netherlands. Zoosymposia, 7, 81-90.

Kallmeyer, J. W., \& Ausich, W. I. (2015). Deepwater occurrence of a new Glyptocrinus (Crinoidea, Camerata) from the Late Ordovician of southwestern Ohio and northern Kentucky: Revision of crinoid paleocommunity composition. Journal of Paleontology, 89, 1068-1075.

McLaughlin, P. I., Brett, C. E., Holland, S. M., \& Storrs, G. W. (Eds.). (2008). Stratigraphic renaissance in the Cincinnati Arch: Implications for Upper Ordovician paleontology and paleoecology. Cincinnati: Cincinnati Museum Center Scientific Contribution 2.

Meyer, D. L., \& Davis, R. A. (2009). A sea without fish: Life in the Ordovician sea of the Cincinnati region. Bloomington: Indiana University Press.

Meyer, D. L., Miller, A. I., Holland, S. M., \& Dattilo, B. F. (2002). Crinoid distribution and feeding morphology through a depositional sequence: Kope and Fairview formation, Upper Ordovician, Cincinnati Arch region. Journal of Paleontology, 76, 725-732.

Meyer, D. L., Tobin, R. C., Pryor, W. A., Harrison, W. B., \& Osgood, R. G. (1981). Stratigraphy, sedimentology, and paleoecology of the Cincinnatian Series (Upper Ordovician) in the vicinity of Cincinnati, Ohio. In T. G. Roberts (Ed.), GSA Cincinnati'81 Field Trip Guidebooks 1 (pp. 31-72). Falls Church: American Geological Institute.

Milam, M. J., Meyer, D. L., Dattilo, B. F., \& Hunda, B. R. (2017). Taphonomy of an Ordovician crinoid Lagerstätte from Kentucky. Palaios, 32, 166-180.

Nagle, J. S. (1967). Wave and current orientation of shells. Journal of Sedimentary Petrology, 37, 1124-1138.

Schwarzacher, W. (1963). Orientation of crinoids by current action. Journal of Sedimentary Petrology, 33, 580-586.

Simms, M. J. (1989). British Lower Jurassic crinoids. London: Monograph of the Palaeontographical Society 142.

Thomka, J. R., \& Brett, C. E. (2017). Insights into the taxonomy and paleoecology of the 'bead bed' crinoid (Echinodermata: Crinoidea) based on new material from the lower Silurian Brassfield Formation of east-central Kentucky. Palaios, 32, 762-768. 